\title{
Factors Influencing Career Preparation Behavior of Mature Age Student Nurses
}

\author{
Lim, Jong $\mathrm{Mi}^{1) \odot} \cdot$ Cho, Ok-Hee ${ }^{2) \odot ~}$ \\ 1) Assistant Professor, Department of Nursing, Shinsung University, Dangiin \\ 2) Professor, Department of Nursing, Kongju National University, Gongju, Korea
}

\begin{abstract}
Purpose: This study was done to determine the correlations among grit, social support, career barriers, and career preparation behavior in mature age nursing students, and identify factors influencing their career preparation behavior. Methods: This cross-sectional, descriptive study included 106 undergraduate nursing students aged 25 years or older at the time of entering three universities in Korea. Grit, social support, career barriers, and career preparation behavior were investigated using structured questionnaires. Data analyses included descriptive statistics, independent t-test, one-way ANOVA, Pearson's correlation analysis, and stepwise multiple regression analysis and were performed with the SAS program (version 9.4). Results: The factors influencing career preparation behavior of mature age nursing students included: persistence of efforts $(\beta=.35, p<.001)$ and consistency of interests $(\beta=-.21, p=.011)$ under the sub-domains of grit; informational support $(\beta=.29, p<.001)$ under the sub-domains of social support; lack of job information $(\beta=-.36, p<.001)$ and anxiety about the future $(\beta=.28$, $p=.008$ ) under the sub-domains of career barriers. These variables accounted for approximately $42 \%$ of the variance in career preparation behavior. Conclusion: The findings imply that in order to improve the career preparation behavior and lower the career barriers of mature age nursing students, their individual cognitive and psychological characteristics should be considered while providing diverse job information as part of career guidance.
\end{abstract}

Key Words: Career choice; Nursing education; Nursing students

Received May 28, 2020 Revised Sep 21, 2020 Accepted Feb 1, 2021

Corresponding author: Cho, Ok-Hee https://orcid.org/0000-0002-8882-675x Department of Nursing, Kongju National University

56 Gongjudeahak-ro, Gongju 32588, Korea

Tel: +82-41-850-0306, Fax: +82-41-850-0315, E-mail: ohcho@kongju.ac.kr 


\section{INTRODUCTION}

The nurses' role in healthcare field has broadened owing to the recent changes in the healthcare system, the opening of the medical market, and the development and introduction of new medical technologies. After investigating 374 medical institutions in Korea, the Korea Health Industry Development Institute found a significant shortage of nurses in $78.1 \%$ of the institutions [1]. To resolve the shortage of nurses, the government has increased the supply of new nurses by creating new nursing departments, expanding the admission quota, and inviting mature age students with work experience via special admission, especially at local universities undergoing a critical fall in student numbers [2]. This occurred not only in Korea but globally, in countries including the U.S., the U.K., and Australia, where the number of mature age students consequently increased as they preferred to go to college prior to employment, re-employment, and transfer to nursing [3-5].

The term mature students" refers to adult learners aged 25 years or older who are considered to be past the normal age of entering university [6]. Following admission, mature age nursing students at universities face various challenges regarding academic life, adaptation to college life, career, and employment [3,7]. During the freshmen or sophomore years, they encounter academic difficulties, such as having to memorize the contents of mandatory or basic medical courses $[5,8]$. They experience remorse and frustration when their academic achievement is low despite spending more time than their younger peers. During their junior or senior years, anxiety about the future regarding age barriers in employment and anticipated difficulties such as their relationship between younger and senior nurses after employment imparts career stress on mature age students [9].

Career preparation behavior refers to the detailed activities and efforts made regarding career decisions and achieving career goals [10]. For nursing students in Korea, graduation from college almost immediately precedes employment. Because of this, once they are enrolled in college, students miss the opportunity to contemplate and explore their aptitude and other career in the field that they major in. Because mature age nursing students vary in terms of their individual characteristics and motivation for admission, often have occupation or work experience prior to their admission and, in some cases, are the main or supporting source of income for the family [11], their career preparation behavior may differ from that of the general population of nursing students [12].
Grit refers to the perseverance and enthusiasm one has towards achieving goals despite not receiving positive feedback or help from others [13]. It is a cognitive and psychological factor that influences career preparation behavior [14]. Grit is an essential factor for nursing students in eliminating any interference in the process of career preparation and in responding to stress [8]. Social support includes any form of positive resources that can be obtained through social relationships and it is a key factor which enhances career preparation behavior [15].

Career barriers, which influence career preparation behavior, include psychological barriers, such as self-concept or accomplishments, and environmental barriers, such as job salary. In a previous study, the academic and career barriers identified by mature age students included the lack of basic learning competence, economic difficulty, and interpersonal difficulty [11], all of which may increase career stress while impeding career preparation behavior. Recently, the type of employment and working conditions in nursing have diversified, and practical problems encountered during clinical training may impose an additional career problem for mature age students [15].

While the number of mature age students entering the nursing department is increasing because they are eager for stable employment and a new challenge in life, studying the characteristics of mature age students and careerrelated variables is crucial for the recruitment of outstanding new students and the management of nursing manpower at medical institutions. Most previous studies on mature age nursing students had small sample sizes and used qualitative methods to report on student's adaptation to college life or the difficulties they faced [4,5]. However, few studies have examined the students' future or career after graduation. Thus, the present study aimed to investigate the influence of grit, social support, and career barriers on career preparation behavior of mature age nursing students.

\section{METHODS}

\section{Study Design}

A cross-sectional and descriptive study was conducted to determine the influence of grit, social support, and career barriers on the career preparation behavior of mature age nursing students.

\section{Study Participants and Data Collection}

This study included 106 students aged 25 years and old- 
er at the time of entering from three universities with fouryear nursing courses in the Chungcheongnam-do province via convenience sampling. To determine the minimum number of participants, multiple regression analysis was conducted using the G-Power 3.1 program with a required effect size of .15 (medium) [16], significance level of .05, and power of test $80 \%$. For five predictors, the minimum required number of participants was 92 . Considering the percentage of drop-outs, 110 questionnaires were distributed and collected. After excluding four questionnaires containing inadequate responses, a total of 106 questionnaires were analyzed.

The study was approved by the institutional review board (IRB) at Kongju National University (IRB No.: KNU _IRB_2019-75). After obtaining permission from the head of the department of nursing, the researcher and two research assistants who had received research ethics education collected data. The study's objectives, questionnaire content, and the right to refuse were explained to the participants and their signed consent forms were collected. Data were collected between October and December 2019, and the questionnaire response time was approximately 20 minutes.

\section{Measures}

\section{1) Career preparation behavior}

Career preparation behavior was measured using the tool developed by Kim and Kim [17]. This tool is a 5-point Likert scale (1 5) consisting of 18 questions: six items on career exploration activity, five items on tool preparation activity, and seven items on goal attainment activity. Responses to each item consisted of a range of $1 \sim 5$, with one point indicating strongly disagree and five points indicating strongly agree. Higher scores indicated that the student participated in more activities related to career preparation behavior. Possible scores range from 18 to 90 . Cronbach's $\alpha$ was .90 (.78 .80).

\section{2) Grit}

Grit was measured using Korean version [18] of the tool developed by Duckworth et al. [14]. This tool is a 5-point Likert scale (1 5) consisting of 12 questions, with six questions under the two domains: Consistency of Interests and Perseverance of Efforts. Responses to each item consisted of a range of $1 \sim 5$, with one point indicating strongly disagree to five points indicating strongly agree. Higher scores indicated higher levels of determination and enthusiasm required for achieving long-term goals. Possible scores range from 12 to 60 . Cronbach's $\alpha$ was .78 (.73 .76).

\section{3) Social support}

Social support was measured using a tool developed by Park [19]. This tool is a 5-point Likert scale (1 5) consisting of 25 questions under four sub-domains: seven questions under emotional support, and six questions each under evaluation support, informational support, and material support. Responses to each item consisted of a range of $1 \sim 5$, with 1 point indicating strongly disagree to 5 points indicating strongly agree. Higher scores indicated higher awareness of social support. Possible scores range from 25 to 125 . Cronbach's $\alpha$ was .96 (.80 .86).

\section{4) Career barriers}

Career barriers were measured using the Career Barrier Inventory developed by Kim [20] for college students. This tool is a 5-point Likert scale (1 5) consisting of 45 questions: five items on interpersonal difficulty, seven items on lack of self-clarity, five items on economic difficulty, five items on conflict with parents and friends, five items on lack of job information, four items on problem related to age, four items on the inferiority of their physical condition, four items on lack of interests, and six items on anxiety about the future. Responses to each item consisted of a range of 1-5, with 1 point indicating strongly disagree to 5 points indicating strongly agree. Higher scores indicated a higher awareness of career barriers. Possible scores range from 45 to 225 . Cronbach's $\alpha$ was .96 (.77 .87).

\section{Data Analysis}

Data were analyzed using the statistics program SAS (version 9.4). The participants' general characteristics, their career preparation behavior, and the levels of variables were described through frequencies, percentages, means, standard deviations, and range while the differences in career preparation behavior based on general characteristics were analyzed through independent t-test and one-way ANOVA. The correlations between career preparation behavior and the variables were determined using Pearson's correlation coefficients, while stepwise multiple regression analysis was used on the variables influencing career preparation behavior.

\section{RESULTS}

\section{General Characteristics of Study Participants}

The mean age of the participants was $34.2 \pm 9.34$ years (range 25 59 years); $44.3 \%$ of which were participants whose ages ranged from 25 30 years. Most were female 
Table 1. Differences in Career Preparation Behavior according to General Characteristics

$(N=106)$

\begin{tabular}{|c|c|c|c|c|}
\hline Characteristics & & $\mathrm{n}(\%)$ & $\mathrm{M} \pm \mathrm{SD}$ & tor $\mathrm{F}(p)$ \\
\hline Age (year) & $\begin{array}{l}25 \sim 30 \\
31 \sim 35 \\
\geq 36\end{array}$ & $\begin{array}{l}47(44.3) \\
18(17.0) \\
41(38.7)\end{array}$ & $\begin{array}{l}53.79 \pm 12.70 \\
47.28 \pm 12.35 \\
54.78 \pm 10.39\end{array}$ & $2.69(.073)$ \\
\hline Gender & $\begin{array}{l}\text { Male } \\
\text { Female }\end{array}$ & $\begin{array}{l}10(9.4) \\
96(90.6)\end{array}$ & $\begin{array}{l}51.40 \pm 15.16 \\
53.24 \pm 11.69\end{array}$ & $-0.46(.646)$ \\
\hline Religion & $\begin{array}{l}\text { Yes } \\
\text { No }\end{array}$ & $\begin{array}{l}32(30.2) \\
74(69.8)\end{array}$ & $\begin{array}{l}54.50 \pm 12.64 \\
52.45 \pm 11.72\end{array}$ & $0.81(.420)$ \\
\hline Marital status & $\begin{array}{l}\text { Married } \\
\text { Unmarried }\end{array}$ & $\begin{array}{l}36(34.0) \\
70(66.0)\end{array}$ & $\begin{array}{l}55.08 \pm 11.56 \\
52.03 \pm 12.14\end{array}$ & $1.25(.216)$ \\
\hline $\begin{array}{l}\text { Subjective economic } \\
\text { level }\end{array}$ & $\begin{array}{l}\text { Good } \\
\text { Moderate } \\
\text { Poor }\end{array}$ & $\begin{array}{c}7(6.6) \\
72(67.9) \\
27(25.5)\end{array}$ & $\begin{array}{l}55.71 \pm 12.41 \\
53.29 \pm 11.40 \\
51.78 \pm 13.64\end{array}$ & $0.34(.716)$ \\
\hline Grade & $\begin{array}{l}\text { Freshmen } \\
\text { Sophomore } \\
\text { Junior }\end{array}$ & $\begin{array}{l}54(50.9) \\
34(32.1) \\
18(17.0)\end{array}$ & $\begin{array}{l}51.46 \pm 11.07 \\
55.82 \pm 13.02 \\
52.67 \pm 12.34\end{array}$ & $1.40(.250)$ \\
\hline $\begin{array}{l}\text { Admission path to } \\
\text { nursing major }\end{array}$ & $\begin{array}{l}\text { Regular decision } \\
\text { Rolling admission } \\
\text { Transfer after graduation from other major }\end{array}$ & $\begin{array}{c}8(7.6) \\
67(63.1) \\
31(29.3)\end{array}$ & $\begin{array}{l}53.75 \pm 15.65 \\
52.81 \pm 11.42 \\
53.45 \pm 12.56\end{array}$ & $0.04(.957)$ \\
\hline $\begin{array}{l}\text { Reason of choice in } \\
\text { nursing major }\end{array}$ & $\begin{array}{l}\text { Employment after graduation } \\
\text { Recommendation of parents and } \\
\text { Aptitude and interest } \\
\text { Have faith in nursing } \\
\text { Related to previous occupation }\end{array}$ & $\begin{array}{c}35(33.0) \\
7(6.6) \\
19(17.9) \\
12(11.3) \\
33(31.2)\end{array}$ & $\begin{array}{l}51.57 \pm 12.88 \\
53.00 \pm 22.49 \\
55.37 \pm 11.68 \\
55.25 \pm 9.63 \\
52.55 \pm 9.14\end{array}$ & $0.42(.796)$ \\
\hline $\begin{array}{l}\text { Pre-admission } \\
\text { occupation }\end{array}$ & $\begin{array}{l}\text { No } \\
\text { Health department } \\
\text { Non- health department }\end{array}$ & $\begin{array}{c}3(2.8) \\
66(62.3) \\
37(34.9)\end{array}$ & $\begin{array}{l}46.00 \pm 8.72 \\
53.94 \pm 11.17 \\
52.08 \pm 13.52\end{array}$ & $0.82(.444)$ \\
\hline $\begin{array}{l}\text { Subjective academic } \\
\text { achievement }\end{array}$ & $\begin{array}{l}\text { High } \\
\text { Middle } \\
\text { Low }\end{array}$ & $\begin{array}{l}10(9.4) \\
69(65.0) \\
27(25.6)\end{array}$ & $\begin{array}{l}48.70 \pm 12.67 \\
54.25 \pm 10.97 \\
51.67 \pm 14.03\end{array}$ & 1.19 (.309) \\
\hline
\end{tabular}

(90.6\%), 69.8\% did not have a religion, $66.0 \%$ were unmarried, and $67.9 \%$ had a "moderate" subjective economic level. Among the participants, 50.9\% were freshmen, $32.1 \%$ were sophomores, and $17.0 \%$ were juniors. Regarding admission to the nursing major, $63.1 \%$ were non-scheduled admissions, and $29.3 \%$ transferred from other departments after graduation. As for their reasons for choosing nursing as a major, "easy employment after graduation" accounted for $33.0 \%$ of responses. As for occupations, $62.3 \%$ had worked in a health department prior to their admission. Regarding their subjective academic achievement in the immediately preceding semester, $65.0 \%$ responded "middle" (Table 1).

\section{Career Preparation Behavior, Grit, Social Support, and Career Barrier}

The mean score of career preparation behavior was 2.95 -points on the 5-point scale. Regarding the sub-domain, they scored highest in career exploration activity (3.27 points), followed by tool preparation activity (2.92 points) and goal attainment activity (2.69 points). They had mean scores of 3.24 points in grit, 3.84 points in social support, and 2.39 points in career barriers (Table 2 ).

\section{Differences in Career Preparation Behavior according to General Characteristics}

No significant differences were found in the career preparation behavior based on general characteristics (Table 1).

\section{Correlations between Career Preparation Beha- vior and the Variables}

There was a positive correlation between career preparation behavior and grit $(\mathrm{r}=.34, p<.001)$ and between ca- 
Table 2. Scores of Career Preparation Behavior, Grit, Social Supports, and Career Barriers

$(N=106)$

\begin{tabular}{|c|c|c|c|c|c|c|}
\hline \multirow{2}{*}{ Variables (number of items) } & \multicolumn{3}{|c|}{ Total score } & \multicolumn{3}{|c|}{ Mean score } \\
\hline & $\mathrm{M} \pm \mathrm{SD}$ & Actual range & Possible range & $\mathrm{M} \pm \mathrm{SD}$ & Actual range & Possible range \\
\hline Career preparation behavior (18) & $53.07 \pm 11.98$ & $20 \sim 87$ & $18 \sim 90$ & $2.95 \pm 0.67$ & $1.11 \sim 4.83$ & $1 \sim 5$ \\
\hline Career exploration activity (6) & $19.64 \pm 4.51$ & $6 \sim 30$ & $6 \sim 30$ & $3.27 \pm 0.75$ & $1.00 \sim 5.00$ & $1 \sim 5$ \\
\hline Tool preparation activity (5) & $14.60 \pm 4.06$ & $5 \sim 25$ & $5 \sim 25$ & $2.92 \pm 0.81$ & $1.00 \sim 5.00$ & $1 \sim 5$ \\
\hline Goal attainment activity (7) & $18.82 \pm 5.03$ & $7 \sim 32$ & $7 \sim 35$ & $2.69 \pm 0.72$ & $1.00 \sim 4.57$ & $1 \sim 5$ \\
\hline Grit (12) & $38.85 \pm 6.15$ & $22 \sim 56$ & $12 \sim 60$ & $3.24 \pm 0.51$ & $1.83 \sim 4.67$ & $1 \sim 5$ \\
\hline Persistence of effort (6) & $18.61 \pm 3.71$ & $9 \sim 28$ & $6 \sim 30$ & $3.10 \pm 0.62$ & $1.50 \sim 4.67$ & $1 \sim 5$ \\
\hline Consistency of interests (6) & $20.24 \pm 3.81$ & $7 \sim 28$ & $6 \sim 30$ & $3.37 \pm 0.64$ & $1.17 \sim 4.67$ & $1 \sim 5$ \\
\hline Social supports (25) & $96.05 \pm 12.76$ & $46 \sim 125$ & $25 \sim 125$ & $3.84 \pm 0.51$ & $1.84 \sim 5.00$ & $1 \sim 5$ \\
\hline Emotional support (7) & $27.10 \pm 3.93$ & $9 \sim 35$ & $7 \sim 35$ & $3.87 \pm 0.56$ & $1.29 \sim 5.00$ & $1 \sim 5$ \\
\hline Evaluation support (6) & $23.79 \pm 3.22$ & $13 \sim 30$ & $6 \sim 30$ & $3.97 \pm 0.54$ & $2.17 \sim 5.00$ & $1 \sim 5$ \\
\hline Informational support (6) & $23.23 \pm 3.43$ & $11 \sim 30$ & $6 \sim 30$ & $3.87 \pm 0.57$ & $1.83 \sim 5.00$ & $1 \sim 5$ \\
\hline Material support (6) & $21.92 \pm 3.37$ & $13 \sim 30$ & $6 \sim 30$ & $3.65 \pm 0.56$ & $2.17 \sim 5.00$ & $1 \sim 5$ \\
\hline Career barriers (45) & $107.53 \pm 27.32$ & 50 199 & $45 \sim 225$ & $2.39 \pm 0.61$ & $1.11 \sim 4.42$ & $1 \sim 5$ \\
\hline Interpersonal difficulty (5) & $12.27 \pm 3.86$ & $5 \sim 25$ & $5 \sim 25$ & $2.45 \pm 0.77$ & $1.00 \sim 5.00$ & $1 \sim 5$ \\
\hline Lack of self-clarity (7) & $18.06 \pm 4.81$ & $7 \sim 35$ & $7 \sim 35$ & $2.58 \pm 0.69$ & $1.00 \sim 5.00$ & $1 \sim 5$ \\
\hline Economic difficulty (5) & $13.00 \pm 4.08$ & $5 \sim 25$ & $5 \sim 25$ & $2.60 \pm 0.82$ & $1.00 \sim 5.00$ & $1 \sim 5$ \\
\hline Conflict with parents (5) & $9.74 \pm 3.76$ & $5 \sim 23$ & $5 \sim 25$ & $1.95 \pm 0.75$ & $1.00 \sim 4.60$ & $1 \sim 5$ \\
\hline Lack of job information (5) & $11.67 \pm 3.61$ & $5 \sim 23$ & $5 \sim 25$ & $2.33 \pm 0.72$ & $1.00 \sim 4.60$ & $1 \sim 5$ \\
\hline Problem of age (4) & $11.11 \pm 3.96$ & $4 \sim 20$ & $4 \sim 20$ & $2.78 \pm 0.99$ & $1.00 \sim 5.00$ & $1 \sim 5$ \\
\hline Physical condition inferiority (4) & $8.43 \pm 3.04$ & $4 \sim 20$ & $4 \sim 20$ & $2.11 \pm 0.76$ & $1.00 \sim 5.00$ & $1 \sim 5$ \\
\hline Lack of interest (4) & $8.75 \pm 2.65$ & $4 \sim 15$ & $4 \sim 20$ & $2.19 \pm 0.66$ & $1.00 \sim 3.75$ & $1 \sim 5$ \\
\hline Anxiety about the future (6) & $14.53 \pm 4.91$ & $6 \sim 30$ & $6 \sim 30$ & $2.42 \pm 0.82$ & $1.00 \sim 5.00$ & $1 \sim 5$ \\
\hline
\end{tabular}

reer preparation behavior and social support $(\mathrm{r}=.46, p<$ .001). However, career preparation behavior was negatively correlated with career barriers $(\mathrm{r}=-.29, p<.001)$ (Table 3$)$.

\section{Factors Influencing the Career Preparation Be- havior}

Before performing the multiple regression, we checked whether our data satisfied the basic assumptions of regression, that is normal distribution of residuals, linearity, homogeneity of variance and multicollinearity. To this end, normal p-p plot of residuals, scatter plot, tolerance and variance inflation factor (VIF) were examined. Residuals were close to the 45-degree line and demonstrated normal distribution, while the scatter plot of the residuals was evenly distributed around 0. Autocorrelation of error was examined with Durbin-Watson coefficients. The values were close to 2, at 2.20, confirming the absence of autocorrelation. Tolerance was above 0.1 , at $0.52 \sim 0.83$, and VIF was also all below 10, at 1.21 1.94, confirming the absence of multicollinearity.

The regression model for career preparation behavior was found to be significant $(\mathrm{F}=13.41, p<.001)$. In other words, the following factors influencing career prepara- tion behavior were identified: perseverance of efforts $(\beta=$ $.35, p<.001)$ and consistency of interests $(\beta=-.21, p=.011)$ under the sub-domain of grit; informational support $(\beta=$ $.29, p<.001$ ) under the sub-domain of social support; and lack of job information $(\beta=-.36, p<.001)$ and anxiety about the future $(\beta=.28, p=.008)$ under the sub-domain of career barriers. These five identified variables predicted approximately $42 \%$ of the career preparation behavior of mature age nursing students, with lack of job information (under the career barriers domain) having the largest influence on career preparation behavior (Table 4).

\section{DISCUSSION}

The emotional maturity and personal experience of mature age nursing students at universities are highly desirable qualities in a nursing professional. Mature age nursing students are also a crucial source of nursing manpower since a high percentage of them stay at one workplace after employment as a nurse or after getting employed by medical institutions [11]. This study investigated the levels of career preparation behavior and variables influencing this in order to develop a program to assist the career preparation behavior of mature age nursing 
Table 3. Correlations between Career Preparation Behavior and Research Variables

\begin{tabular}{|c|c|c|c|c|}
\hline \multirow{3}{*}{ Variables } & \multicolumn{4}{|c|}{ Career preparation behavior } \\
\hline & Total & $\begin{array}{c}\text { Career exploration } \\
\text { activity }\end{array}$ & $\begin{array}{c}\text { Tool preparation } \\
\text { activity }\end{array}$ & $\begin{array}{l}\text { Goal } \\
\text { attainment activity }\end{array}$ \\
\hline & $\mathrm{r}(p)$ & $r(p)$ & $\mathrm{r}(p)$ & $r(p)$ \\
\hline Grit & $.34^{* *}$ & $.22^{*}$ & $.36^{* *}$ & $.34^{* *}$ \\
\hline Persistence of effort & .06 & -.01 & .08 & .10 \\
\hline Consistency of interests & $.49^{* *}$ & $.36^{* *}$ & $.49^{* *}$ & $.44^{* *}$ \\
\hline Social supports & $.46^{* *}$ & $.56^{* *}$ & $.33^{* *}$ & $.33^{* *}$ \\
\hline Emotional support & $.42 * *$ & $.52 * *$ & $.30^{*}$ & $.28^{*}$ \\
\hline Evaluation support & $.43^{* *}$ & $.54^{* *}$ & $.30^{*}$ & $.29^{*}$ \\
\hline Informational support & $.45^{* *}$ & $.53^{* *}$ & $.33^{* *}$ & $.33^{* *}$ \\
\hline Material support & $.39 * *$ & $.47^{\star *}$ & $.27^{*}$ & $.30^{*}$ \\
\hline Career barriers & $-.29^{*}$ & $-.22^{*}$ & $-.21^{*}$ & $-.41^{* *}$ \\
\hline Interpersonal difficulty & $-.25^{*}$ & $-.21^{*}$ & -.17 & $-.34^{* *}$ \\
\hline Lack of self-clarity & $-.33^{* *}$ & $-.27^{*}$ & $-.27^{*}$ & $-.52^{* *}$ \\
\hline Economic difficulty & -.16 & -.13 & -.07 & -.16 \\
\hline Conflict with parents and friends & -.06 & -.02 & -.02 & $-.26^{*}$ \\
\hline Lack of job information & $-.46^{* *}$ & $-.36^{* *}$ & $-.42 * *$ & $-.45^{* *}$ \\
\hline Problem of age & -.11 & -.09 & -.12 & $-.20^{*}$ \\
\hline Physical condition inferiority & $-.25^{*}$ & -.18 & -.13 & -.19 \\
\hline Lack of interest & $-.32^{* *}$ & $-.28^{*}$ & $-.28^{*}$ & $-.48^{* *}$ \\
\hline Anxiety about the future & -.13 & -.09 & .06 & $.29^{*}$ \\
\hline
\end{tabular}

${ }^{*} p<.05,{ }^{* *} p<.01$.

Table 4. Factors Influencing Career Preparation Behavior

$(N=106)$

\begin{tabular}{|c|c|c|c|c|c|c|}
\hline Predictors & B & SE & Standardized $\beta$ & $\mathrm{t}$ & $95 \% \mathrm{CI}$ & $p$ \\
\hline Intercept & 0.95 & 0.63 & & 1.52 & $-0.29 \sim 2.20$ & .132 \\
\hline Consistency of interests ${ }^{\dagger}$ & -0.23 & 0.09 & -.21 & -2.59 & $-0.07 \sim-0.01$ & .011 \\
\hline Persistence of effort ${ }^{\dagger}$ & 0.37 & 0.09 & .35 & 4.01 & $0.03 \sim 0.09$ & $<.001$ \\
\hline Informational support $^{\dagger}$ & 0.34 & 0.10 & .29 & 3.42 & $0.02 \sim 0.09$ & $<.001$ \\
\hline Lack of job information ${ }^{\S}$ & -0.33 & 0.10 & -.36 & -3.42 & $-0.10 \sim-0.03$ & $<.001$ \\
\hline Anxiety about the future ${ }^{\S}$ & 0.22 & 0.08 & .28 & 2.70 & $0.01 \sim 0.06$ & .008 \\
\hline
\end{tabular}

$\mathrm{CI}=$ confidence interval; $\mathrm{SE}=$ standard error; ${ }^{\dagger}$ Sub-domain of the grit; ${ }^{\dagger}$ Sub-domain of social support; ${ }^{\S}$ Sub-domain of career barriers.

students. The mature age nursing students had a mean score of 2.95-point on a 5-point scale regarding the level of career preparation behavior, which is higher than the score of nursing students under 25 years old (95.8\% of subjects are under 25 years of age, 2.58 points) [16]. Undergraduate mature age nursing students showed a higher level of career preparation behavior presumably due to their higher sensitivity towards health care policies and changes in the social environment than the general nursing students [3], and having a higher level of anxiety regarding the age barrier in employment [21].

The factors influencing career preparation behavior of mature age nursing students were identified as follows. First, under the sub-domain of grit, the higher the perseverance of efforts and the lower the consistency of interests, the more the career preparation behaviors increased. This differed from results of another report, wherein all the sub-domains of grit in general college students influenced their career preparation behavior. In particular, consistency of interests was reported to have a significantly positive effect on career preparation behavior [22]. However, this study found that a lower consistency of interests, which means a student's interests change more often, led to more career preparation behaviors. Hence, it is im- 
portant to develop a practical and tailored program which identifies mature nursing students' changing needs and helps them to explore their career options. Mature age students had a mean score of 3.24 points (out of 5) with regard to the level of grit, which is higher than that of younger nursing students (3.01 points)[23]. A previous study [24] supported this study's results, showing that the reasons adult learners had a higher level of grit than college students were that adult learners recognized that persistence and effort are critical based on their social experience, remained interested in their major, and maintained their passion and tenacity while juggling with their work and family life after they chose to pursue further studies. Therefore, the higher level of grit in mature age students as compared to younger students is thought to be due to strong motivation, enthusiasm, and perseverance that drove them to pursue college education for academic or employment purposes. Thus, grit is an individual characteristic that should be considered in the career guidance of mature age students.

Mature age students are presumed to have consistently maintained the will to continue college education and interests in their majoring field because they had previously experienced numerous challenges in society. They can set realistic goals within the domain of their capability [13]. As some mature age nursing students identified professors' prejudice as a source of difficulty in their school life, teachers should show them continuous attention and improve their student's self-esteem by sharing various success stories about other similar students [4]. In addition, counseling and guidance from the faculty is essential for mature age nursing students to set the right career goals that reflect their abilities and to remain motivated in realizing their goals.

Second, in this study, the informational support under the sub-domain of social support was recognized by mature students as a factor that increased career preparation. It is presumed that the nursing department's unique education process, that allows students to simultaneously lean and prepare for their career has led students to recognize the strong informational support for their career. In other words, undergraduate nursing students have an opportunity to determine whether or not they are fit for their career through direct experience during practical training in the hospital and receiving career-related information from the healthcare facility where they are trained [26]. Furthermore, students improve their career exploration behavior through indirect experience in simulation-based practical training and have opportunities to select the department that suits their aptitude or to check whether they can adapt to their occupation [27].

Informational support was the only variable that influenced career preparation behavior under the sub-domain of social support. Career information regarding various nursing fields should be collected and provided for mature students. Social support tends to change with time or circumstance; therefore, mature age students' needs regarding the information should be regularly analyzed in order to provide career information that reflects the latest employment environment.

Third, under the sub-domain of career barriers, the more that job information was provided and the higher their anxiety about the future, the higher the increase in career preparation behavior of mature age students. This differed from the results of general nursing students who scored higher in terms of lack of self-clarity and inferiority of physical condition [25]. The fact that lack of job information (career barriers) and informational support (social support) were identified as factors influencing career preparation behavior implies a high demand of mature age students for useful and practical information about career activities [5].

Although mature age nursing students have a strong determination towards employment with relatively stable career goals [24] various barriers may prevent them from adopting effective career preparation behaviors. Therefore, career barriers should be analyzed to devise a plan that will help mature age nursing students with their career preparation behaviors. While mature age nursing students do not falter despite setback and are persistent and enthusiastic about their efforts to begin a new academic life and about the future, they may also potentially experience anxiety and uncertainty caused by personal or social barriers [3]. In nursing departments in the U.S., the U.K., and Australia, various specialized programs are available for mature age students [11]. In contrast, the career and employment information provided by nursing departments in Korea is relatively restricted in a set frame, limiting career information and support provided to mature age students based on their characteristics [28]. Therefore, individuals who perceive having more career barriers are more likely to have a difficult time being confident in their career decisions [29]. Since the way an individual recognizes and interprets career barriers influences their career preparation behavior [30], individual expectations and demands regarding career should be analyzed rather than focusing solely on eliminating career barriers. Thus, a distinguished system of administrative support and career preparation programs should be established to assist the students in planning their careers and prepare in a systematic way from the moment they enter university. 
This study recruited mature age nursing students from three university in Korea, which makes it difficult to generalize the results. Nevertheless, the findings are significant. This is the first study to identify the factors influencing the career preparation behavior of mature age nursing students and to provide basic data which will aid mature age students in successfully adjusting to their new college life and in providing career guidance.

\section{CONCLUSION}

This study investigated the levels of grit, social support, career barriers, and the career preparation behavior of mature age nursing students, and determined their correlations as well as the factors influencing career preparation behavior. The findings indicated that the more mature age students made persistent efforts and maintained a consistent interest toward career and the more informational support increased, the more their career preparation behavior became proactive. On the other hand, lack of job information and anxiety about the future led to reduced career preparation behavior. The study results can serve as basic data to establish a system of career guidance and support and enhance the career preparation behaviors of mature undergraduate nursing students, which should be consistent with the changes in the social role and awareness of nurses. Career guidance should consider the cognitive and psychological characteristics of individual mature age nursing students, and personalized career preparation programs should be developed and applied to ensure that proactive responses are made toward career barriers and that students are provided with employment information about various nursing fields.

\section{CONFLICTS OF INTEREST}

The authors declared no conflict of interest.

\section{REFERENCES}

1. Korea Health Industry Development Institute. Small and medium hospital management support and policy development report [Internet]. Cheongju: Korea Health Industry Development Institute; 2014 [cited 2015 March 13]. Available from: https://www.khidi.or.kr/board/view?linkId=147287\&menu $\mathrm{Id}=\mathrm{MENU} 00085$

2. Lee T, Kang KH, Ko YK, Cho SH, Kim EY. Issues and challenges of nurse workforce policy: a critical review and implication. Journal of Korean Academy of Nursing Administration. 2014; 20(1):106-116. https://doi.org/10.11111/jkana.2014.20.1.106

3. O'brien F, Keogh B, Neenan K. Mature students' experiences of undergraduate nurse education programmes: the Irish experience. Nurse Education Today. 2009;29(6):635-640.

https://doi.org/10.1016/j.nedt.2009.01.008

4. Cho YM, Kim EJ, Sok SH. Older nursing students' college life experiences. Journal of the Korea Contents Association. 2019; 19(2):671-683. https:// doi.org/10.5392/JKCA.2019.19.02.671

5. Elmir R, Ramjan LM, Everett B, Salamonson Y. Nursing students' experiences of repeating units in an undergraduate program: a qualitative study. Nurse Education Today. 2019;79: 147-152. https://doi.org/10.1016/j.nedt.2019.05.024

6. Lee JH, Ahn YS. Qualitative research on the experiences of campus life for adult learners. Journal of Lifelong Education. 2007;13(3):89-116.

7. Koo HY, Park OK, Jo KW. Experience of career decision of Korean nursing students. Child Health Nursing Research. 2017;23(2):168-178.

https://doi.org/10.4094/chnr.2017.23.2.168

8. Terry D, Peck B. Academic and clinical performance among nursing students: what's grit go to do with it? Nurse Education Today. 2020;88:104371.

https://doi.org/10.1016/j.nedt.2020.104371

9. Kenny A, Kidd T, Nankervis K, Connell S. Mature age students access, entry and success in nurse education: an action research study. Contemporary Nurse. 2011;38(1-2):106-118.

https://doi.org/10.5172/conu.2011.38.1-2.106

10. Cho MS, Choi KS. A model testing on ego-identity, social support, career decision-making self-efficacy, career maturity, and career preparation behavior in late adolescence. Korean Journal of Counseling. 2007;8(3):1085-1099.

11. Hayden LJ, Jeong SY, Norton CA. An analysis of factors affecting mature age students' academic success in undergraduate nursing programs: a critical literature review. International Journal of Nursing Education Scholarship. 2016;13(1):127-138. https://doi.org/10.1515/ijnes-2015-0086

12. Ko YJ, Kim IK. The relationship between professional nursing values and career preparation behaviors of nursing students. Korean Academic Social Nursing Education. 2011;17(1):62-71. https://doi.org/10.5977/JKASNE.2011.17.1.062

13. Young-Brice A, Dreifuers KT. Exploring grit among black prelicensure nursing students. Nursing Education Perspective. 2020;41(1):46-48. https://doi.org/10.1097/01.NEP.0000000000000473

14. Duckworth AL, Peterson C, Matthews MD, Kelly DR. Grit: perseverance and passion for long-term goals. Journal of Personality and Social Psychology. 2007;92(6):1087-1101. https://doi.org/10.1037/0022-3514.92.6.1087

15. Hirschi A, Niles SG, Akos P. Engagement in adolescent career preparation: social support, personality and the development of choice decidedness and congruence. Journal of Adolescence. 2011;34(1):173-182. 
https://doi.org/10.1016/j.adolescence.2009.12.009

16. Moon JY. Mediating effect of self-leadership and career decision-making self-efficacy on the relation between critical thinking disposition and career preparation behavior in nursing students. The Journal of the Korea Contents Association. 2019; 19(11):462-473. https:// doi.org/10.5392/JKCA.2019.19.11.462

17. Kim BW, Kim KH. Career decision level and career preparation behavior of the college students. The Korean Journal of Counseling and Psychotherapy. 1997;9(1):311-333.

18. Lee S, Sohn YW. What are the strong predictors of academic achievement? - deliberate practice and Grit. The Korean Journal of School Psychology. 2013;10(3):349-366. https://doi.org/10.16983/kjsp.2013.10.3.349

19. Park JW. A study to development a scale of social support [dissertation]. Seoul: Yonsei University; 1985. p. 1-127.

20. Kim EY. A study for the development and validation of the Korean college students' career barrier Inventory. The Korean Journal of Counseling and Psychotherapy. 2002;14(1):219-240.

21. Paik YR, Song BN. The conflict experiences of adult learner in college life. Journal of Qualitative Research. 2015;16(2):85-95. https://doi.org/10.22284/qr.2015.16.2.85

22. Jang YR, Huh JY. The effect of grit on career decision making self-efficacy and career preparation behaviors of university students in physical education. The Korean Society of Sports Science. 2019;28(4):819-834.

https://doi.org/10.35159/kjss.2019.08.28.4.819

23. Park JY, Woo CH, Kim JE. Convergence factors affecting the grit of nursing students experiencing clinical practice. Journal of Digital Convergence. 2018;16(1):165-175. https://doi.org/10.14400/JDC.2018.16.1.165

24. Jeong E. Effects of grit and everyday creativity on subjective well-being for adult learners and college students. The Journal of Learner-Centered Curriculum and Instruction. 2019;19(16):
163-192. https://doi.org/10.22251/jlcci.2019.19.16.163

25. Choi HJ, Jung KI. Moderating effects of career decision-making self-efficacy and social support in the relationship between career barriers and job-seeking stress among nursing students preparing for employment. Journal of Korean Academy of Nursing Administration. 2018;24(1):61-72. https://doi.org/10.11111/jkana.2018.24.1

26. Lee EJ, Kim HJ, Park EB, Park JH, Jeong MJ, Jeong JH. The effect of clinical practice satisfaction, career search efficacy, and major satisfaction on career preparation behavior in nursing students. Journal of Learner-Centered Curriculum and Instruction. 2018;18(1):263-278. https://doi.org/10.22251/jlcci.2018.18.1.263

27. Jeong M, Seo Y. The effect of simulation-based practice education on employability, career exploration behavior and decision-making self-efficacy of the nursing students. The Korean Society of Applied Science and Technology. 2019;36(3):709-725. https://doi.org/10.12925/jkocs.2019.36.3.709

28. Han J, Lee N. A study on improvement in career guidance of nursing. Journal of Learner-Centered Curriculum and Instruction. 2018;18(23):969-987.

https://doi.org/10.22251/jlcci.2018.18.23.969

29. Wright SL, Perrone-McGovern KM, Boo JN, White AV. Influential factors in academic and career self-efficacy: attachment, supports, and career barriers. Journal of Counseling \& Development. 2014;92(1):36-46. https://doi.org/10.1002/j.1556-6676.2014.00128.x

30. Kim Y, Ham EH, Kim TS. The effect of career barrier on female adult learners' career preparation: the mediating effect of calling. Journal of Learner-Centered Curriculum and Instruction. 2018;18(8):803-822.

https://doi.org/10.22251/jlcci.2018.18.8.803 